\title{
The effect of a chronic maternal cortisol infusion on the late-gestation fetal sheep
}

\author{
E C Jensen, B W Gallaher, B H Breier and J E Harding
}

Research Centre for Developmental Medicine and Biology, School of Medicine, Private Bag 92019, Auckland, New Zealand

(Requests for offprints should be addressed to J E Harding, The Liggins Institute, Faculty of Medicine and Health Science, Private Bag 92019, Auckland, New Zealand)

\begin{abstract}
Exposure of the fetus to excess maternal glucocorticoids has been postulated to alter fetal growth and development, and thus provide a possible mechanism for the link between impaired fetal growth and altered postnatal physiology. However, the effects of exposure to excess maternal glucocorticoids on fetal physiology and metabolism in utero have not been described. We therefore studied the effects of chronic maternal cortisol infusion on fetal growth, blood pressure, metabolism and endocrine status in chronically catheterised fetal sheep. We infused hydrocortisone $(80 \mathrm{mg} /$ day, $n=6)$ or saline $(n=8)$ for 10 days into the pregnant ewes beginning at 119 days of gestation. Maternal cortisol infusion reduced fetal growth rate by $30 \%$ (girth increment $2.9 \pm 0.3$ vs $1.8 \pm 0.4 \mathrm{~mm} /$ day, $P=0 \cdot 03$ ). Maternal cortisol infusion increased fetal heart weight by $15 \%$ relative to body weight and increased ventricular wall thickness by $30 \%$ in the left and $50 \%$ in the right ventricle. The weight of the spleen was reduced by $30 \%$ and placental weight reduced by $25 \%$. Fetal blood
\end{abstract}

pressure increased by approximately $10 \mathrm{mmHg}$ (20\%) during maternal cortisol infusion.

Maternal cortisol infusion did not alter amino-nitrogen concentrations. However, maternal lactate concentrations increased by $80 \%$ and fetal lactate concentrations increased by $74 \%$ with maternal cortisol infusion, and both maternal and fetal urea concentrations increased by $40 \%$. Circulating maternal IGF-binding protein (IGFBP)-3 levels had increased by $20 \%$ by the end of the maternal cortisol infusion. Fetal IGF-I concentrations decreased during cortisol infusion and fetal IGFBP-1 concentrations were negatively correlated with fetal weight $(r=-0 \cdot 76$, $P=0 \cdot 02$ ).

We conclude that even a modest elevation of maternal cortisol levels affects fetal growth, cardiovascular function, metabolism and endocrine status which may have longterm consequences.

Journal of Endocrinology (2002) 174, 27-36

\section{Introduction}

In postnatal life, administration of glucocorticoids has effects on multiple organ systems, including inhibition of growth, elevation of blood pressure, altered carbohydrate and protein metabolism and altered endocrine status (Loeb 1976, Tonolo et al. 1988). A number of these effects have also been demonstrated in fetal life.

Glucocorticoid infusions into pregnant monkeys, sheep and mice have resulted in retarded fetal growth (Reinisch et al. 1978, Novy \& Walsh 1983, Fowden et al. 1996). Repeated maternal but not fetal doses of betamethasone to the late-gestation pregnant sheep also caused reductions in birthweight, and weights of the placenta and major organs (Newnham et al. 1998). Elevated glucocorticoids in the fetal sheep have been shown to increase fetal blood pressure (Hill et al. 1988, Tangalakis et al. 1992). Acute cortisol infusion in the fetal sheep decreased amino acid uptake (Milley 1995, 1996) and dexamethasone infused for 2 days increased circulating concentrations of amino acids and depressed umbilical glucose uptake (Barbera et al. 1997).

There have been a number of studies of the effects of glucocorticoids on the fetus in which investigators have infused cortisol in high doses directly into the fetus to simulate the prepartum cortisol surge (Milley 1995, 1996, Fowden et al. 1996) or given acute high-dose cortisol infusions to the mother (Wood \& Rudolph 1984). However, there have been no studies of the effects of chronically elevated maternal cortisol levels within the physiological range on the fetus in utero. It has been proposed that excessive fetal exposure to maternal glucocorticoids may be an important mechanism linking impaired fetal growth to the increased risk of cardiovascular and metabolic disease in adulthood (Edwards et al. 1993, Seckl 1997).

Therefore, the present study was designed to investigate the effects of a chronic low-dose maternal cortisol infusion on fetal growth, blood pressure, metabolism and endocrine responses in late gestation but before the prepartum cortisol increase in sheep. 


\section{Materials and Methods}

\section{Animal preparation}

Fourteen pregnant Romney/Dorset cross-bred ewes of known gestation carrying singleton fetuses underwent surgery under halothane anaesthesia at $113 \pm 0 \cdot 7$ days of gestation. Polyvinyl catheters were placed in both fetal femoral arteries and veins via the tarsal vessels. An amniotic catheter was sutured to one of the fetal hindlimbs. A growth catheter (nylon fishing line inside a polyethylene catheter) was sutured to each side of the fetal chest from sternum to spine to measure fetal growth (Mellor \& Murray 1982, Harding 1997). Catheters were also placed in the maternal femoral artery and vein, carotid artery and jugular vein.

The ewes were housed in individual cages with free access to water and pelleted stock feed. Gentamycin $(80 \mathrm{mg} / \mathrm{ml})$ was given intravenously to the fetus and Streptopen $(250 \mathrm{mg}$ procaine penicillin/250 mg dihydrostreptomycin sulphate; Pittman Moore Ltd, Upper Hutt, NZ) was given by intramuscular injection to the ewe daily for the first 3 postoperative days. All catheters were flushed daily for the first 3 days with a solution of heparin (10 $\mathrm{U} / \mathrm{ml}$ ) in $0.9 \%$ saline. At the end of the experiment $(128 \pm 0 \cdot 4$ days of gestation) the ewe was killed with an overdose of phenobarbitone. The fetus, fetal organs and placenta were dissected, measured and weighed and the positions of all the catheters were checked. Cardiac ventricular wall thickness was measured by micrometer, as the thickness of the free wall at the point halfway between the apex and the base. A portion of the apex was removed and frozen in liquid nitrogen for later determination of protein and DNA content. Placentomes were categorised by shape according to the method of Vatnick et al. (1991). All experiments were approved by the institutional Animal Ethics Committee.

\section{Experimental protocol}

The animals were allowed 5 days to recover from surgery. On day 6, experimental ewes received hydrocortisone (Solu-cortef; Upjohn Company, Kalamazoo, MI, USA; $80 \mathrm{mg} /$ day $)(n=6)$ by continuous infusion into the maternal femoral vein for 10 days. Controls $(n=8)$ received the same volume of saline. Blood samples $(10 \mathrm{ml}$ maternal, $8 \mathrm{ml}$ fetal) were taken before beginning the infusion and on alternate days thereafter.

Maternal and fetal arterial blood pressure (corrected for amniotic pressure) and heart rate were recorded for $12 \mathrm{~h}$ overnight and the mean value was taken for each measurement. Blood pressure and heart rate were recorded at three different time-points; before, in the middle and at the end of the cortisol infusion. Heart rate was derived from the arterial pulse frequency. Signals were processed and averaged over 1-min intervals using Labview for Windows (National Instruments, Austin, TX, USA).
Growth catheters were measured twice daily and the mean value used to calculate increase in fetal girth. All values were normalised to zero on the first postoperative day, and were validated against post-mortem measurements as described elsewhere (Harding 1997).

\section{Sample handling}

Blood was collected in sterile heparinised syringes and aliquoted into separate tubes in frozen gel blocks for later measurement of metabolites. Additional aliquots were centrifuged and the plasma collected for later hormone assay. All samples were then frozen at $-80{ }^{\circ} \mathrm{C}$. A separate aliquot of blood was set aside on ice for a maximum of $15 \mathrm{~min}$ before measurement of blood gases using a Chiron M845 blood gas analyser (Chiron Corporation, Emeryville, CA, USA).

\section{Assays}

All assays were validated for maternal and fetal sheep plasma with appropriate control samples included in each assay. Aliquots of blood stored at $-80{ }^{\circ} \mathrm{C}$ were deproteinised with sulphuric acid and sodium tungstate (glucose, urea and amino-nitrogen assay) or perchloric acid (lactate assay). Glucose, urea and lactate were measured by standard colorimetric enzyme reactions (Hochella \& Weinhouse 1965, Kunst et al. 1984, Kerscher \& Ziegenhorn 1985) using a 96-well microplate reader. Amino-nitrogen was assayed by colorimetric reaction with $\beta$-napthoquinone sulphonate (Evans et al. 1993). Protein was measured by the Lowry method (Lowry et al. 1951, Kresze 1994), and DNA determined by fluorescence bound to Hoechst 33258 (Labarca \& Paigen 1980). Cortisol was measured by radioimmunoassy (RIA) (Minton et al. 1992). Insulin-like growth factor (IGF)-I concentrations in plasma were measured by doubleantibody RIA after acid-ethanol cryoprecipitation (Breier et al. 1993, Blum \& Breier 1994). IGF-II was also measured in plasma by double-antibody RIA (Breier et al. 1998). IGF-binding protein (IGFBP)-1 was measured using a double-antibody RIA method (Hennies et al. 1998). IGFBP-3 was obtained from plasma by using acid extraction and IGF-II affinity chromatography, and then measured by double-antibody RIA (Gallaher et al. 1998). Angiotensin II in plasma was measured by RIA after extraction with ethanol (Nicholls \& Espiner 1976). Angiotensin I, generated by the action of renin on its endogenous substrate angiotensinogen in these samples, was measured by RIA (Dunn \& Espiner 1976). Plasma renin activity (nmol angiotensin I produced/litre plasma per h) was then calculated.

\section{Statistical analysis}

Morphometric measurements and growth rates were compared between groups using unpaired $t$-tests and 
Table 1 Effect of maternal cortisol infusion on organ weights and organ to body weight ratios. Data are expressed as means \pm S.E. for eight controls and five cortisol-infused animals

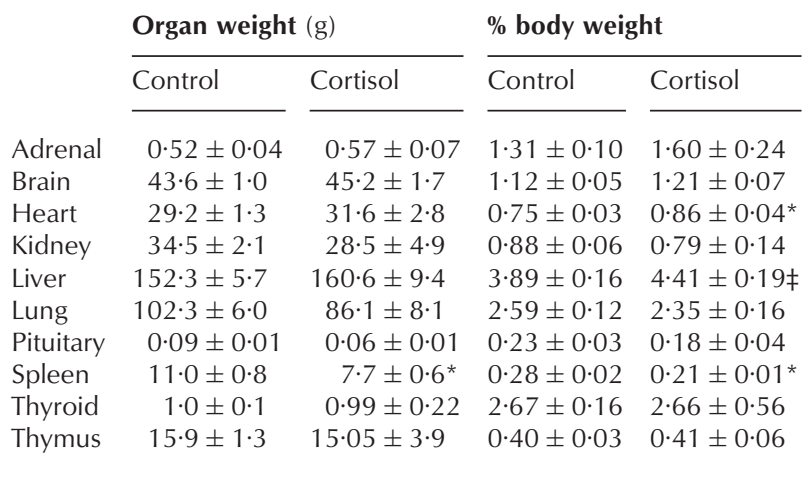

Organ to body weight ratios are multiplied by a factor of 100 (adrenal, pituitary and thyroid are multiplied by an additional factor of 100).

${ }^{*} P<0 \cdot 05, \neq P=0.06$ for comparison between groups.

chi-squared analysis as appropriate. Changes in metabolites and hormones during the experiment were compared using two-way repeated measures analysis of variance. Maternal IGFBP-1, renin, glucose and IGF-II as well as fetal IGFBP-1, cortisol, lactate and heart rate were analysed after logarithmic transformation in order to normalise the data. Differences between individual means were compared by Fisher's LSD test for post hoc comparisons. Relationships between variables were tested using simple linear regression. Fetal gender was included as a covariate in the analyses where appropriate. Data are expressed as mean \pm s.E. For technical reasons not all data were available for all animals. In particular, post-mortem data were not obtained for one cortisol-infused animal, and metabolite and hormone data for two control animals.

\section{Results}

\section{Fetal measurements and organ weights}

Fetuses of cortisol-infused and control ewes did not differ in weight $(3658 \pm 226 \mathrm{~g}$ vs $3933 \pm 119 \mathrm{~g})$ or length $(42.7 \pm 1 \cdot 0 \mathrm{~cm}$ vs $43 \cdot 1 \pm 0.7 \mathrm{~cm})$. However, fetuses of cortisol-infused ewes tended to be thinner than controls $(31.9 \pm 1.0 \mathrm{~cm}$ vs $33.8 \pm 0.5 \mathrm{~cm}, P=0.09)$. They also had lighter spleens than control fetuses (Table 1). When organ weights were expressed relative to body weight, spleen weight was still reduced, while heart weight was increased by $15 \%$ in fetuses of cortisol-infused ewes. Ventricular wall thickness was also increased (left $8.4 \pm 0.3$ vs $6.5 \pm 0.5 \mathrm{~mm}, P=0.01$; right $7 \cdot 9 \pm 0.4$ vs $5.3 \pm 0.6 \mathrm{~mm}$, $P<0 \cdot 01)$.

The ratio of male to female fetuses was $5: 3$ for controls and 2:4 for cortisol-infused animals. Males were 20\%

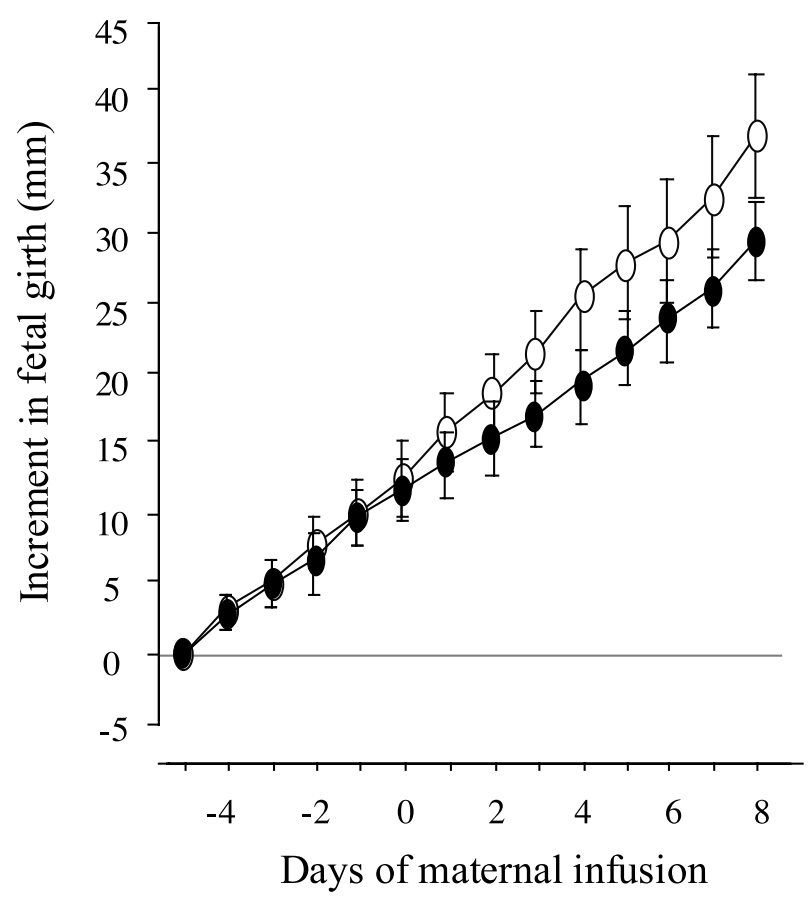

Figure 1 Fetal growth during maternal cortisol or saline infusion. Growth is slower in fetuses of cortisol-infused animals (1.8 \pm $0 \cdot 4$ vs $2 \cdot 9 \pm 0 \cdot 3 \mathrm{~mm} /$ day, $P<0 \cdot 05)$. Values are means \pm S.E. for five cortisol-exposed animals $(\boldsymbol{O})$ and seven control animals $(\bigcirc)$. Measurements were normalised to zero on the first postoperative day. Not all data were available for the last 2 days of infusion, which have therefore been omitted from this graph.

heavier than females $(F=6 \cdot 8, P<0 \cdot 01)$, but there was no significant fetal gender $\times$ treatment interaction.

Fetal growth rate, as measured by increment in fetal girth, was not different between cortisol-infused and control fetuses before cortisol infusion $(3.1 \pm 0.3 \mathrm{~mm} /$ day vs $3 \cdot 3 \pm 0.6 \mathrm{~mm} /$ day). Maternal cortisol infusion reduced fetal growth rate by $30 \%$ during the infusion $(1 \cdot 8 \pm 0 \cdot 4$ vs $2 \cdot 9 \pm 0.3 \mathrm{~mm} /$ day, $P<0 \cdot 05)$ (Fig. 1).

\section{Placenta}

Maternal cortisol infusion decreased placental weight by approximately $25 \%$ (Table 2). The fetal to placental weight ratio was also increased in the cortisol-exposed animals $(7 \cdot 89 \pm 0 \cdot 42$ vs $9 \cdot 99 \pm 0 \cdot 45, P<0 \cdot 05)$. Maternal cortisol infusion did not significantly alter total placentome number. However, cortisol-infused animals had fewer A and more $\mathrm{B}$ type placentomes $(P<0 \cdot 001)$. In addition, placentomes in categories A and B were lighter.

\section{Protein/DNA in heart tissue}

Protein concentrations in the fetal heart were not different between cortisol-infused and control groups $(26 \cdot 2 \pm 1 \cdot 3$ vs $24 \cdot 0 \pm 0 \cdot 6 \mathrm{mg} / \mathrm{g}$ wet tissue). DNA concentration was also 
Table 2 Effect of maternal cortisol infusion on the placenta. Data are expressed as means \pm S.E. for eight controls and five cortisol-infused animals

$\begin{array}{lccc} & \text { Control } & & \text { Cortisol } \\ \begin{array}{l}\text { Total placental weight }(\mathrm{g}) \\ \text { Mean placentome weight }(\mathrm{g})\end{array} & 508 \pm 30 & & 381 \pm 31^{*} \\ \quad \text { Category A } & 5 \cdot 9 \pm 0 \cdot 2 & & 3 \cdot 5 \pm 0 \cdot 2^{* * *} \\ \text { Category B } & 6 \cdot 7 \pm 0 \cdot 5 & & 5 \cdot 3 \pm 0 \cdot 2^{* * *} \\ \text { Category C } & 8 \cdot 2 \pm 0 \cdot 6 & & 7 \cdot 7 \pm 0 \cdot 6 \\ \text { Category D } & 3 \cdot 6 \pm 0 \cdot 8 & & 0 \\ \text { Total no. of placentomes } & 81 \pm 4 & & 84 \pm 6 \\ \text { Mean placentome number } & & \\ \text { Category A } & 58 \pm 7 & & 30 \pm 18^{* * *} \\ \text { Category B } & 14 \pm 6 & & 40 \pm 16 \\ \text { Category C } & 8 \pm 5 & & 11 \pm 10 \\ \text { Category D } & 0 \cdot 3 \pm 0 \cdot 3 & \\ \end{array}$

Placentomes were divided using categories described by Vatnick et al. (1991).

${ }^{*} P<0 \cdot 05,{ }^{* * *} P<0 \cdot 001$ for comparison between groups.

not different $(6 \cdot 0 \pm 0 \cdot 4$ vs $5 \cdot 6 \pm 0 \cdot 4 \mathrm{mg} / \mathrm{g}$ wet tissue), and thus protein/DNA ratios were similar in cortisol-exposed and control fetal hearts $(4 \cdot 5 \pm 0 \cdot 5$ vs $4 \cdot 4 \pm 0 \cdot 3)$.

\section{Blood pressure and heart rate}

Before infusion, mean arterial blood pressure in both mother and fetus was not different between cortisolinfused and control animals (mother: $85 \cdot 2 \pm 3 \cdot 0$ vs $79 \cdot 1 \pm$ $5 \cdot 2 \mathrm{mmHg}$; fetus: $43.7 \pm 1.9$ vs $41.8 \pm 1.0 \mathrm{mmHg}$ ). Maternal cortisol infusion did not change maternal blood pressure, but increased fetal blood pressure by $30 \%$ $(\mathrm{F}=3.7, P<0.05)$ (Fig. 2). Maternal and fetal heart rate could not be compared between groups because signal loss from the blood pressure trace meant that there were insufficient data available for comparison.

\section{Metabolites}

Before infusion, there were no differences between groups in maternal or fetal concentrations of glucose, lactate, amino-nitrogen or urea (Table 3). Maternal cortisol infusion increased maternal blood glucose concentrations $(\mathrm{F}=7 \cdot 5, P<0 \cdot 05)$ but fetal glucose concentrations were not significantly increased. Maternal lactate concentrations increased by approximately $80 \%(\mathrm{~F}=6 \cdot 0, P<0 \cdot 001)$ and fetal lactate concentrations increased by $74 \%(\mathrm{~F}=4 \cdot 0$, $P<0 \cdot 01)$ by the end of infusion. Maternal cortisol infusion did not change maternal amino-nitrogen concentrations. Fetal amino-nitrogen concentrations rose transiently in both groups during the infusion period, but there was no effect of maternal cortisol infusion. Maternal urea concentrations increased in both groups during the infusion period and were significantly higher in the cortisol-infused animals $(\mathrm{F}=4 \cdot 0, P<0 \cdot 01)$. Maternal cortisol infusion also

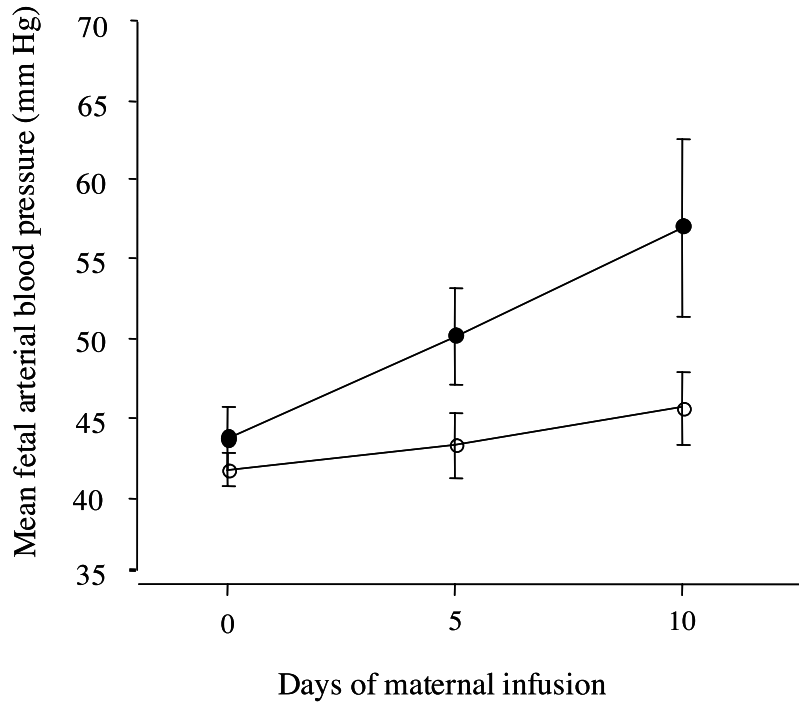

Figure 2 Mean fetal arterial blood pressure over a 10-day maternal cortisol or saline infusion. Blood pressure is higher in fetuses of cortisol-infused animals $(P<0 \cdot 05)$. Values are means \pm S.E. for five cortisol-exposed animals $(\bullet)$ and seven controls $(\bigcirc)$.

increased fetal urea levels $(\mathrm{F}=2 \cdot 9, P<0 \cdot 05)$. Maternal and fetal arterial $\mathrm{PO}_{2}$, haemoglobin concentration and $\mathrm{pH}$ were not different between groups and did not change during infusion (data not shown).

\section{Hormones and binding proteins}

Before maternal cortisol infusion there were no significant differences between groups in maternal or fetal plasma concentrations of cortisol, angiotensin II, renin activity, IGF-I, IGF-II, IGFBP-1 or IGFBP-3 (Table 4). Maternal cortisol concentrations approximately doubled in the cortisol-infused group, but this change did not reach statistical significance. Fetal cortisol concentrations increased with gestation in both groups and were higher in the cortisol-infused group than in controls $(\mathrm{F}=3 \cdot 1$, $P<0 \cdot 05)$. Maternal cortisol concentrations tended to correlate positively with fetal concentrations in the cortisolinfused group $(r=0 \cdot 25, P=0 \cdot 07)$ but not control animals $(r=0 \cdot 14, P=0 \cdot 45)$. Neither maternal nor fetal concentrations of renin or angiotensin II changed with cortisol infusion.

Maternal cortisol infusion did not change maternal circulating concentrations of IGF-I. However, maternal cortisol infusion decreased fetal IGF-I concentrations $(\mathrm{F}=3 \cdot 0, P<0 \cdot 05)$. Maternal IGFBP-3 concentrations were increased during maternal cortisol infusion $(\mathrm{F}=3 \cdot 1$, $P<0 \cdot 05)$, but fetal IGFBP-3 concentrations were unchanged, as were IGF-II and IGFBP-1 concentrations in both mother and fetus. 
Table 3 Effect of maternal cortisol infusion on fetal and maternal blood metabolite concentrations. Values are means \pm S.E. $\mathrm{mmol} / /$ for six control and six cortisol-treated animals

\begin{tabular}{|c|c|c|c|c|}
\hline & \multicolumn{2}{|l|}{ Maternal } & \multicolumn{2}{|l|}{ Fetal } \\
\hline & Control & Cortisol & Control & Cortisol \\
\hline Glucose & & ${ }^{*} \dagger$ & & \\
\hline Day 0 & $2 \cdot 25 \pm 0 \cdot 16$ & $2 \cdot 32 \pm 0 \cdot 21$ & $0 \cdot 88 \pm 0 \cdot 09$ & $0 \cdot 81 \pm 0 \cdot 04$ \\
\hline Day 2 & $2 \cdot 22 \pm 0 \cdot 18$ & $2 \cdot 64 \pm 0 \cdot 10$ & $0.86 \pm 0.09$ & $1 \cdot 03 \pm 0 \cdot 10$ \\
\hline Day 4 & $2 \cdot 18 \pm 0 \cdot 18$ & $2 \cdot 49 \pm 0 \cdot 16$ & $0 \cdot 86 \pm 0 \cdot 11$ & $0 \cdot 94 \pm 0 \cdot 12$ \\
\hline Day 7 & $2 \cdot 29 \pm 0 \cdot 18$ & $2 \cdot 99 \pm 0 \cdot 26$ & $0 \cdot 87 \pm 0 \cdot 10$ & $1 \cdot 00 \pm 0 \cdot 16$ \\
\hline Day 9 & $2 \cdot 32 \pm 0 \cdot 14$ & $2 \cdot 50 \pm 0 \cdot 26$ & $0 \cdot 93 \pm 0 \cdot 10$ & $1 \cdot 00 \pm 0 \cdot 16$ \\
\hline Lactate & & $* * * \dagger$ & & $* *+†$ \\
\hline Day 0 & $0.54 \pm 0.06$ & $0.42 \pm 0.04$ & $1 \cdot 17 \pm 0 \cdot 10$ & $0 \cdot 84 \pm 0.06$ \\
\hline Day 2 & $0.55 \pm 0.06$ & $0.65 \pm 0.06$ & $1 \cdot 27 \pm 0 \cdot 33$ & $1 \cdot 17 \pm 0.06$ \\
\hline Day 4 & $0.44 \pm 0.05$ & $0 \cdot 74 \pm 0 \cdot 10$ & $1 \cdot 33 \pm 0 \cdot 15$ & $1 \cdot 20 \pm 0 \cdot 03$ \\
\hline Day 7 & $0.47 \pm 0.04$ & $0.60 \pm 0.08$ & $1 \cdot 42 \pm 0 \cdot 16$ & $2 \cdot 05 \pm 0 \cdot 73$ \\
\hline Day 9 & $0.55 \pm 0.05$ & $0 \cdot 75 \pm 0 \cdot 11$ & $1 \cdot 23 \pm 0 \cdot 16$ & $1 \cdot 46 \pm 0 \cdot 16$ \\
\hline Amino-nitrogen & & & ††† & $\dagger$ \\
\hline Day 0 & $4 \cdot 75 \pm 0 \cdot 27$ & $5 \cdot 49 \pm 0 \cdot 33$ & $7 \cdot 35 \pm 0 \cdot 15$ & $7 \cdot 39 \pm 0 \cdot 42$ \\
\hline Day 2 & $4 \cdot 96 \pm 0 \cdot 27$ & $5 \cdot 19 \pm 0 \cdot 21$ & $7 \cdot 74 \pm 0 \cdot 21$ & $7 \cdot 68 \pm 0 \cdot 41$ \\
\hline Day 4 & $4 \cdot 90 \pm 0 \cdot 24$ & $4 \cdot 54 \pm 0 \cdot 25$ & $7 \cdot 28 \pm 0 \cdot 14$ & $7 \cdot 21 \pm 0 \cdot 46$ \\
\hline Day 7 & $4 \cdot 71 \pm 0 \cdot 19$ & $4 \cdot 74 \pm 0 \cdot 39$ & $7 \cdot 19 \pm 0 \cdot 21$ & $6.96 \pm 0.48$ \\
\hline Day 9 & $4.52 \pm 0 \cdot 23$ & $4 \cdot 65 \pm 0 \cdot 30$ & $7 \cdot 07 \pm 0 \cdot 15$ & $7 \cdot 37 \pm 0 \cdot 25$ \\
\hline Urea & †† & ${ }^{* *}+\dagger \dagger$ & & ${ }^{*}+\dagger$ \\
\hline Day 0 & $3 \cdot 54 \pm 0.33$ & $3 \cdot 72 \pm 0 \cdot 38$ & $4 \cdot 27 \pm 0 \cdot 45$ & $4 \cdot 09 \pm 0 \cdot 25$ \\
\hline Day 2 & $3 \cdot 85 \pm 0 \cdot 31$ & $5 \cdot 07 \pm 0 \cdot 40$ & $4 \cdot 67 \pm 0 \cdot 34$ & $5 \cdot 22 \pm 0 \cdot 29$ \\
\hline Day 4 & $4 \cdot 10 \pm 0 \cdot 45$ & $5 \cdot 24 \pm 0 \cdot 15$ & $4.52 \pm 0.53$ & $5 \cdot 63 \pm 0.27$ \\
\hline Day 7 & $4 \cdot 37 \pm 0 \cdot 48$ & $4 \cdot 51 \pm 0 \cdot 33$ & $4 \cdot 86 \pm 0.57$ & $4 \cdot 66 \pm 0 \cdot 20$ \\
\hline Day 9 & $4 \cdot 33 \pm 0 \cdot 61$ & $4 \cdot 53 \pm 0 \cdot 25$ & $4 \cdot 48 \pm 0 \cdot 54$ & $5 \cdot 8 \pm 0 \cdot 40$ \\
\hline
\end{tabular}

Fetal IGF-I concentrations were 53\% higher in male than in female fetuses $(P<0 \cdot 01)$, and fetal IGFBP-3 concentrations were $24 \%$ higher $(P<0 \cdot 05)$. However, there was no significant treatment $\times$ gender interaction for IGF-I and IGFBP-3 concentrations.

When data from both groups were combined, and concentrations were taken over the 10-day infusion period, IGFBP-1 concentrations tended to be positively correlated with mean fetal cortisol concentrations $(r=0 \cdot 27$, $P=0 \cdot 06)$ and negatively correlated with fetal IGF-I concentrations $(r=-0 \cdot 67, P<0 \cdot 001)$. Fetal IGFBP-1 concentrations averaged for days 7 and 9 were negatively correlated with fetal weight $(r=-0 \cdot 76, P<0 \cdot 05)$.

\section{Discussion}

We have shown that a chronic maternal cortisol infusion to the late-gestation pregnant ewe reduced fetal growth, increased fetal blood pressure and affected maternal and fetal metabolism. This is the first in vivo demonstration of the chronic effects of increased maternal cortisol concentrations within the physiological range on the mother and fetus.
We infused cortisol at a rate estimated to be two to three times the maternal production rate $(\sim 25 \mathrm{mg}$ /day) (Liggins et al. 1973), aiming to achieve elevated maternal levels within the physiological range. We achieved a doubling in maternal cortisol concentrations which, although not statistically significant, appeared to be adequate to influence fetal concentrations as demonstrated by the increase in fetal cortisol concentrations, and the positive correlation between maternal and fetal cortisol concentrations in the cortisol-infused group. Much greater increases in cortisol have been observed in response to physiologic stressors, such as a sevenfold increase in response to hypoxia (Boddy et al. 1974).

\section{Fetal growth}

We showed that a 10-day low-dose maternal cortisol infusion reduced fetal growth rate by approximately one third and resulted in thinner fetuses at post-mortem. This is consistent with previous findings that direct infusion of cortisol to the late-gestation fetal sheep in doses high enough to reach circulating levels seen near term reduced fetal growth but did not significantly alter fetal weight (Fowden et al. 1996). Increased maternal glucocorticoid 
Table 4 Effect of maternal cortisol on maternal and fetal plasma cortisol, IGF-I, IGF-II, IGFBP-1, IGFBP-3, renin and angiotensin levels. Data are expressed as means \pm S.E. for six control and six cortisol-infused animals

\begin{tabular}{|c|c|c|c|c|}
\hline & Maternal & & Fetal & \\
\hline & Control & Cortisol & Control & Cortisol \\
\hline Cortisol (nmol/l) & & & $\dagger$ & *t十† \\
\hline Day 0 & $39 \cdot 6 \pm 6 \cdot 9$ & $27 \cdot 8 \pm 3 \cdot 4$ & $19 \cdot 0 \pm 1 \cdot 6$ & $14 \cdot 9 \pm 2 \cdot 2$ \\
\hline Day 2 & $40 \cdot 1 \pm 10 \cdot 9$ & $70 \cdot 2 \pm 18 \cdot 4$ & $19 \cdot 9 \pm 5 \cdot 0$ & $25 \cdot 9 \pm 4 \cdot 2$ \\
\hline Day 4 & $37 \cdot 8 \pm 8 \cdot 0$ & $49 \cdot 0 \pm 10 \cdot 0$ & $22 \cdot 1 \pm 2 \cdot 1$ & $30 \cdot 6 \pm 9 \cdot 1$ \\
\hline Day 7 & $41 \cdot 3 \pm 9 \cdot 6$ & $74 \cdot 5 \pm 24 \cdot 7$ & $19 \cdot 0 \pm 1 \cdot 5$ & $44 \cdot 4 \pm 12 \cdot 4$ \\
\hline Day 9 & $35 \cdot 0 \pm 6 \cdot 0$ & $35 \cdot 3 \pm 11 \cdot 6$ & $37 \cdot 2 \pm 11 \cdot 9$ & $31 \cdot 7 \pm 3 \cdot 5$ \\
\hline Angiotensin II (pmol/l) & & & ††十 & \\
\hline Day 0 & $32 \cdot 5 \pm 3 \cdot 7$ & $23 \cdot 6 \pm 4 \cdot 3$ & $73 \pm 21$ & $60 \cdot 8 \pm 18 \cdot 6$ \\
\hline Day 2 & & & & \\
\hline Day 4 & $32 \cdot 7 \pm 4 \cdot 8$ & $22 \cdot 8 \pm 4 \cdot 3$ & $89 \cdot 2 \pm 14 \cdot 5$ & $62 \cdot 5 \pm 11 \cdot 1$ \\
\hline Day 7 & & & & \\
\hline Day 9 & $26 \cdot 2 \pm 2 \cdot 5$ & $26 \pm 7 \cdot 5$ & $41 \cdot 5 \pm 7 \cdot 1$ & $45 \cdot 5 \pm 5 \cdot 8$ \\
\hline $\begin{array}{l}\text { Plasma renin activity } \\
(\mathrm{nmol} / \mathrm{l} \text { per } \mathrm{h})\end{array}$ & & & $\dagger$ & $\dagger$ \\
\hline Day 0 & $0 \cdot 5 \pm 0 \cdot 1$ & $0 \cdot 5 \pm 0 \cdot 1$ & $1 \cdot 7 \pm 0 \cdot 6$ & $3 \cdot 0 \pm 1 \cdot 6$ \\
\hline Day 2 & & & & \\
\hline Day 4 & $0 \cdot 5 \pm 0 \cdot 1$ & $0 \cdot 5 \pm 0 \cdot 2$ & $2 \cdot 7 \pm 0 \cdot 4$ & $3 \cdot 3 \pm 0 \cdot 6$ \\
\hline Day 7 & & & & \\
\hline Day 9 & $0 \cdot 4 \pm 0 \cdot 1$ & $0 \cdot 7 \pm 0 \cdot 3$ & $1 \cdot 1 \pm 0 \cdot 3$ & $1 \cdot 1 \pm 0 \cdot 2$ \\
\hline IGF-I (ng/ml) & & & & * \\
\hline Day 0 & $155 \pm 16$ & $139 \pm 11$ & $91 \pm 9$ & $96 \pm 8$ \\
\hline Day 2 & $160 \pm 20$ & $136 \pm 8$ & $92 \pm 13$ & $110 \pm 11$ \\
\hline Day 4 & $167 \pm 17$ & $158 \pm 12$ & $91 \pm 12$ & $101 \pm 18$ \\
\hline Day 7 & $169 \pm 18$ & $175 \pm 14$ & $99 \pm 15$ & $87 \pm 28$ \\
\hline Day 9 & $160 \pm 7$ & $207 \pm 20$ & $110 \pm 11$ & $84 \pm 36$ \\
\hline IGF-II (ng/ml) & & & & \\
\hline Day 0 & $315 \pm 6$ & $263 \pm 17$ & $517 \pm 54$ & $580 \pm 29$ \\
\hline Day 2 & $302 \pm 8$ & $247 \pm 17$ & $552 \pm 25$ & $621 \pm 38$ \\
\hline Day 4 & $320 \pm 8$ & $214 \pm 28$ & $506 \pm 34$ & $548 \pm 56$ \\
\hline Day 7 & $313 \pm 8$ & $225 \pm 21$ & $447 \pm 45$ & $429 \pm 70$ \\
\hline Day 9 & $319 \pm 13$ & $274 \pm 47$ & $559 \pm 33$ & $501 \pm 46$ \\
\hline IGFBP-1 (ng/ml) & & & & \\
\hline Day 0 & $1 \cdot 9 \pm 0.7$ & $1 \cdot 9 \pm 0.7$ & $6 \cdot 0 \pm 1 \cdot 1$ & $6 \cdot 1 \pm 1 \cdot 2$ \\
\hline Day 2 & $2 \cdot 8 \pm 1 \cdot 1$ & $0 \cdot 8 \pm 0 \cdot 2$ & $8 \cdot 8 \pm 3 \cdot 6$ & $7 \cdot 0 \pm 1 \cdot 7$ \\
\hline Day 4 & $2.9 \pm 0.6$ & $1 \cdot 3 \pm 0 \cdot 4$ & $8 \cdot 1 \pm 2 \cdot 2$ & $10 \cdot 1 \pm 3 \cdot 0$ \\
\hline Day 7 & $2 \cdot 1 \pm 0 \cdot 6$ & $1 \cdot 1 \pm 0 \cdot 5$ & $5 \cdot 8 \pm 1 \cdot 9$ & $18 \cdot 2 \pm 11 \cdot 7$ \\
\hline Day 9 & $3 \cdot 0 \pm 0 \cdot 9$ & $1 \cdot 0 \pm 0 \cdot 5$ & $6 \cdot 6 \pm 1 \cdot 0$ & $23 \cdot 9 \pm 20 \cdot 3$ \\
\hline IGFBP-3 (ng/ml) & & * & & \\
\hline Day 0 & $2237 \pm 105$ & $2569 \pm 276$ & $1860 \pm 112$ & $2144 \pm 146$ \\
\hline Day 2 & $2402 \pm 139$ & $2435 \pm 244$ & $1927 \pm 163$ & $2099 \pm 172$ \\
\hline Day 4 & $2727 \pm 229$ & $2827 \pm 279$ & $1916 \pm 146$ & $2179 \pm 222$ \\
\hline Day 7 & $2547 \pm 204$ & $3313 \pm 364$ & $1709 \pm 91$ & $1946 \pm 292$ \\
\hline Day 9 & $2551 \pm 208$ & $3138 \pm 354$ & $1855 \pm 78$ & $1912 \pm 230$ \\
\hline
\end{tabular}

Not all data were available for all time-points. Data were excluded from the last time-point for statistical analysis of maternal IGFBP-3 due to insufficient data.

${ }^{*} P<0.05$ for comparison between groups; $\dagger P<0 \cdot 05,++\uparrow P<0 \cdot 001$ for comparison within groups.

exposure during pregnancy in several species is associated with reduced fetal weight (Warrell \& Taylor 1968, Reinisch et al. 1978, Novy \& Walsh 1983). We found that maternal cortisol infusion reduced the weight of the fetal spleen. Our findings are similar to other studies which have shown that a higher dose and longer duration of increased maternal glucocorticoids during pregnancy than the current study resulted in smaller fetal spleens in primates (Novy \& Walsh 1983).

One of the most pronounced effects of maternal cortisol infusion was on the fetal heart. Fetal heart weight increased relative to fetal weight, and wall thickness 
increased by $30 \%$ in the left and $50 \%$ in the right ventricle. Cardiac ventricular hypertrophy has previously been demonstrated in both rat pups (Sicard \& Werner 1992) and preterm infants (Evans 1994) given dexamethasone. The mechanism by which this occurs is unknown. Elevated blood pressure can cause cardiac hypertrophy possibly by increasing afterload to the heart (Murotsuki et al. 1997). Thus the observed increase in fetal blood pressure in our study may have caused the increase in heart size. It is not clear in this study whether the increase in relative heart size and ventricular wall thickness represents cardiac hypertrophy or hyperplasia or both. Although we found that cortisol infusion did not change protein/DNA ratios in the fetal myocardium, DNA concentrations would be an unreliable measure of myocardial cell number if there was a mixture of mono- and binucleated cells. However, the finding that protein and DNA concentrations did not change suggests that the increase in heart to body weight ratio was not due to water.

\section{Placenta}

Placental weight was reduced with maternal cortisol infusion. This finding is similar to previous studies of maternal glucocorticoid administration to other species (Blackburn et al. 1965, Johnson et al. 1979). In lategestation sheep, there is an increase in placental surface area and transport capacity in the last third of gestation even though maximal size has been reached (Battaglia \& Meschia 1986). Maternal cortisol infusion may have inhibited these processes from occurring. Increased maternal cortisol levels may also affect placental metabolism, in particular glycogen deposition, which could affect placental and/or fetal growth (Blackburn et al. 1965). Thus reduced placental weight and possibly impaired function could explain, in part, the reduction seen in fetal growth rate observed in this study. Maternal dexamethasone treatment to the mid-gestation sheep has also been shown to alter placentome weight (Tangalakis et al. 1995). Maternal cortisol infusion in our study increased the numbers of placentomes of the everted type (category B) which is more typical late in gestation (Alexander \& Williams 1966). This increase in placentome type which has a greater proportion of fetal to maternal tissue than the A type, may reflect accelerated placental maturation and have important implications for nutrient transport to the fetus.

\section{Blood pressure}

Maternal cortisol infusion in this study did not alter maternal blood pressure but caused a large rise in fetal blood pressure. In previous studies, high doses of glucocorticoids administered for a short time to the fetal sheep increase blood pressure to a similar extent to that seen in this study, with no change in heart rate (Hill et al. 1988,
Derks et al. 1997). In addition, it has been reported that dexamethasone treatment to pregnant rats during the last third of gestation produces elevated blood pressure in the offspring (Levitt et al. 1996). Thus, based on postnatal data by others, the current study suggests that even moderate elevation of maternal glucocorticoids in utero may have postnatal consequences. However, it is not known how long maternal glucocorticoids need to be elevated before causing irreversible postnatal effects. Although we found that plasma renin and angiotensin II concentrations were unchanged with cortisol infusion, previous investigators have shown that glucocorticoids may increase vascular sensitivity to vasoconstrictors such as angiotensin II and catecholamines in the fetus and adult (Berecek et al. 1980, Tangalakis et al. 1992, Whitworth et al. 1995).

\section{Metabolites}

Maternal glucose concentrations were increased by maternal cortisol infusion. This is consistent with previous findings that cortisol administration to the adult results in increased glucose release from the liver, increased glycogenesis leading to glycogen deposition, and a decreased peripheral utilisation of glucose (White et al. 1968).

Both maternal and fetal lactate concentrations increased with maternal cortisol infusion. This may have been the result of increased placental lactate production, as the placenta is known to release lactate into both maternal and fetal circulations (Burd et al. 1975). Another possible explanation for increased lactate concentrations in cortisolinfused animals could be an effect on fetal and maternal lactate production. Lactate in the sheep placenta is derived from glucose taken up by both the fetal and maternal circulations and lactate is also produced from glucose in fetal tissues (Sparks et al. 1982). Cortisol has been shown to increase the storage of glucose in a variety of fetal tissues (Fowden et al. 1998). Therefore it is possible that, in the current study, increased circulating lactate concentrations were the result of increased glucose storage and lactate production. It is also possible that there was increased production of lactate from glucose as a result of reduced glucose demand for fetal growth.

Maternal cortisol infusion did not alter amino-nitrogen concentrations in the mother or fetus. This is in contrast to previous studies showing that administration of cortisol or dexamethasone to fetal sheep decreased fetal aminonitrogen uptake (Milley 1996) and increased fetal plasma concentrations of many amino acids (Barbera et al. 1997). However, both these studies used doses much higher than those in our study. In addition, postnatal data in humans showed that infusing two different high doses of cortisol overnight resulted in an increase in plasma concentrations of amino acids with increasing rate of cortisol infusion (Brillon et al. 1995). Thus an effect of cortisol on amino acid concentrations may be dose-dependent. It is not known whether cortisol infusion altered individual amino 
acid concentrations in this study. Maternal cortisol infusion did increase maternal and fetal blood urea concentrations. Since urea production is a measure of protein oxidation in the fetus (Gresham et al. 1972), increased blood urea concentrations could indicate increased fetal protein oxidation. This would be consistent with previous findings that fetal cortisol infusion in late-gestation sheep increases fetal protein breakdown (Milley 1995).

\section{Hormones}

We found that fetal IGF-I concentrations were decreased during cortisol infusion. The fall in fetal IGF-I concentrations could at least partly explain the decrease observed in fetal growth, as previous studies have shown that in postnatal animals cortisol acts to inhibit growth by downregulating production of IGF-I (Loeb 1976). There were no significant differences in circulating fetal IGFBP concentrations between cortisol-exposed and control animals. However, mean fetal IGFBP-1 concentrations tended to be positively correlated with mean fetal cortisol concentrations and negatively correlated with IGF-I concentrations and fetal weight. These relationships suggest that cortisol might influence fetal growth through modulation of fetal IGFBP-1 concentrations. It has been shown that plasma levels of IGFBP-1 correlate with IGF-inhibitory activity in diabetic serum (Taylor et al. 1990) and IGFBP-1 inhibits the growth of chick embryo cartilage in vitro (Burch et al. 1990). IGFBP-1 concentrations are also related to cortisol concentrations in newborns (Cianfarani et al. 1998) and children (Martinelli et al. 1999). Thus it is possible that, in this study, cortisol exposure may have increased fetal IGFBP-1 expression, thus modulating local actions of IGF-I and reducing fetal growth.

Previous human studies have shown that IGFBP-3 concentrations in cord blood are higher in girls than boys (Coutant et al. 2001). IGF-I concentrations in preterm neonates have also been reported to be higher in girls than boys (Bloomfield et al. 2001). In contrast, we found higher IGFBP-3 and IGF-I concentrations in male fetuses in this study. Presumably this reflects the faster growth rate of male fetuses in late gestation, although the mechanisms are unclear. These gender differences in endocrine status did not appear to influence the fetal responses to maternal cortisol infusion in this study.

\section{Direct versus indirect effects of maternal cortisol infusion}

It is not clear from our study whether maternal cortisol infusion affected the fetus directly or indirectly. Since approximately half of the cortisol circulating in the fetus is of maternal origin at the time of our study (Beitins et al. 1973), and there was an increase in fetal cortisol concentrations in the infused group, a direct action of the infused cortisol on the fetus may have contributed to the effects that we observed. Alternatively, maternal cortisol could have been acting indirectly on the fetus by altering maternal metabolic or endocrine status. Finally, maternal cortisol infusion could have inhibited fetal growth by altering placental structure and function. The reduction in placental weight observed with maternal cortisol infusion could have resulted in reduced transport capacity and impaired function.

In summary, we have shown that chronic modest elevation of maternal cortisol concentrations can affect the growth, metabolism and cardiovascular function of the fetus. This may be through direct fetal exposure to maternal glucocorticoids, effects on maternal metabolic and endocrine status, and/or effects on placental structure and function. Our study supports the growing body of literature suggesting that fetal exposure to excess glucocorticoids might provide a link between early life events and later disease.

\section{Acknowledgements}

C Keven, T Smith-Wong and Dr M Bauer provided excellent technical assistance. E C J was supported by a Lottery Health Research Scholarship. These experiments were also supported by the Health Research Council of New Zealand.

\section{References}

Alexander G \& Williams D 1966 Progesterone and placental development in the sheep. Journal of Endocrinology 34 241-245.

Barbera A, Wilkening RB, Teng C, Battaglia FC \& Meschia G 1997 Metabolic alterations in the fetal hepatic and umbilical circulations during glucocorticoid-induced partuition in sheep. Pediatric Research $41242-248$.

Battaglia FC \& Meschia G 1986. An Introduction to Fetal Physiology. Orlando: Academic Press, Inc.

Beitins IZ, Bayard F, Ances IG, Kiwarski A \& Migeon CJ 1973 The metabolic clearance rate, blood production, interconversion and transplacental passage of cortisol and cortisone in pregnancy near term. Pediatric Research 7 509-519.

Berecek KH, Stocker M \& Gross F 1980 Changes in renal vascular reactivity at various stages of deoxycorticosterone hypertension in rats. Circulation Research 46 619-624.

Blackburn WR, Kaplan HS \& McKay DG 1965 Morphologic changes in the developing rat placenta following prednisolone administration. American Journal of Obstetrics and Gynecology 92 234-246.

Blum WF \& Breier BH 1994 Radioimmunoassays for insulin-like growth factors and their binding proteins. Growth Regulation $\mathbf{4}$ (Suppl.) 11-19.

Bloomfield FH, Knight DB, Breier BH \& Harding JE 2001 Growth restriction in dexamethasone-treated preterm infants may be mediated by reduced IGF-I and IGFBP-3 plasma concentrations. Clinical Endocrinology 54 235-242.

Boddy K, Jones CT, Mantell C, Ratcliffe JG \& Robinson JS 1974 Changes in plasma ACTH and corticosteroid of the maternal and fetal sheep during hypoxia. Endocrinology 94 588-591.

Breier BH, Milsom SR, Blum WF, Schander J, Gallaher BW \& Gluckman PD 1993 Insulin-like growth factors and their binding 
proteins in plasma and milk after growth hormone stimulated galactopoiesis in normally lactating women. Acta Endocrinology 129 427-435.

Breier BH, Hennies M, Vickers MH, Gallaher BW, Keven CI \& Gluckman PD 1998 Insulin-like growth factor-2 in sheep plasma shows marked diurnal variation and is altered by growth hormone and endotoxin treatment. The Endocrine Society 80th Annual Meeting, New Orleans 1-116.

Brillon DJ, Zheng B, Campbell RG \& Matthews DE 1995 Effect of cortisol on energy expenditure and amino acid metabolism in humans. American Journal of Physiology 268 E501-E513.

Burch WM, Correa J, Shivley JE \& Powell DR 1990 The 25-kilodalton insulin-like growth factor (IGF)-binding protein inhibits both basal and IGF-I mediated growth of chick embryo pelvic cartilage in vitro. Journal of Clinical Endocrinology and Metabolism 70 173-180.

Burd LI, Jones MD Jr, Simmons MA, Makowski EL, Meschia G \& Battaglia FC 1975 Placental production and foetal utilization of lactate and pyruvate. Nature 254 210-211.

Cianfarani S, Germani D, Rossi L, Argiro G, Boemi S, Lemon M, Holly JMP \& Branca F 1998 IGF-I and IGF-binding protein-I are related to cortisol in human cord blood. European Journal of Endocrinology 138 524-529.

Coutant R, Boux de Casson F, Douay O, Mathieu E, Rouleau S, Beringue F, Gillard P, Limal JM \& Descamps P 2001 Relationships between placental GH concentration and maternal smoking, newborn gender, and maternal leptin: possible implications for birth weight. Journal of Clinical Endocrinology \& Metabolism 86 4854-4859.

Derks JB, Giussani DA, Jenkins SL, Wentworth RA, Visser GHA, Padbury JF \& Nathanielsz PW 1997 A comparitive study of cardiovascular, endocrine and behavioural effects of betamethasone and dexamethasone administration to fetal sheep. Journal of Physiology 499 217-226.

Dunn PJ \& Espiner EA 1976 Outpatient screening tests for primary aldosteronism. Australia and New Zealand Journal of Medicine 6 131-135.

Edwards CRW, Benediktsson R, Lindsay RS \& Seckl JR 1993 Dysfunction of placental glucocorticoid barrier: link between fetal environment and adult hypertension. The Lancet 341 355-357.

Evans N 1994 Cardiovascular effects of dexamethasone in the preterm infant. Archives of Disease in Childhood 70 F25-F30.

Evans PC, Ffolliott-Powell FM \& Harding JE 1993 A colorimetric assay for amino nitrogen in small volumes of blood: reaction with B-Naphthoquinone sulfonate. Analytical Biochemistry 208 334-337.

Fowden AL, Szemere J, Hughes P \& Gilmour RS 1996 The effects of cortisol on the growth rate of the sheep fetus during late gestation. Journal of Endocrinology 151 97-105.

Fowden AL, Li J \& Forhead AJ 1998 Glucocorticoids and the preparation for life after birth: are there long-term consequences of the life insurance. Proceedings of the Nutrition Society 57 1-11.

Gallaher BW, Breier BH, Keven CL, Harding JE \& Gluckman PD 1998 Fetal programming of insulin-like growth factor (IGF)-I and IGF-binding protein-3: evidence for an altered response to undernutrition in late gestation following exposure to periconceptual undernutrition in the sheep. Journal of Endocrinology 159 501-508.

Gresham EL, James EJ, Raye JR, Battaglia FC, Makowski EL \& Meschia G 1972 Production and excretion of urea by the fetal lamb. Pediatrics 50 372-379.

Harding JE 1997 Prior growth rate determines the fetal growth response to acute maternal undernutrition in fetal sheep of late gestation. Prenatal and Neonatal Medicine 2 300-309.

Hennies M, Gallaher BW, Keven CI, Funk B, Gluckman PD \& Breier BH 1998 The endotoxin-induced IGF binding protein-1 increase is diminished by growth hormone. The Endocrine Society 80th Annual Meeting, New Orleans 1-110.
Hill KJ, Lumbers ER \& Elbourne I 1988 The actions of cortisol on fetal renal function. Journal of Developmental Physiology 10 85-96.

Hochella NJ \& Weinhouse S 1965 Automated lactic acid determination in serum and tissue extracts. Analytical Biochemistry 10 304-317.

Johnson JWC, Mitzner W, London WT, Palmer AE \& Scott R 1979 Betamethasone and the rhesus fetus: multisystemic effects. American Journal of Obstetrics and Gynecology 133 677-684.

Kerscher L \& Ziegenhorn J 1985 Urea. In Methods of Enzymatic analysis, pp 444-453. Ed. HU Bergmeyer. Weinheim, Germany: Verlag Chemie.

Kresze GB 1994 Methods for protein determination. In Methods of Enzymatic analysis, pp 84-97. Ed. HU Bergmeyer. Weinheim, Germany: Verlag Chemie.

Kunst A, Draeger B \& Ziegenhorn J 1984 Colorimetric methods with glucose oxidase and peroxidase. In Methods of Enzymatic Analysis, pp 178-185. Ed. HU Bergmeyer. Weinheim, Germany: Verlag Chemie.

Labarca C \& Paigen K 1980 A simple, rapid, and sensitive DNA assay procedure. Analytical Biochemistry 102 344-352.

Levitt NS, Linsay RS, Holmes MC \& Seckl JR 1996 Dexamethasone in the last week of pregnancy attenuates hippocampal glucocorticoid receptor gene expression and elevates blood pressure in the adult offspring in the rat. Neuroendocrinology 64 412-418.

Liggins GC, Fairclough RJ, Grieves SA, Kendall JZ \& Knox BS 1973 The mechanism of initiation of parturition in the ewe. Recent Progress in Hormone Research 29 111-150.

Loeb JN 1976 Corticosteroids and growth. The New England Journal of Medicine 295 547-552.

Lowry OH, Rosebrough NJ, Farr AL \& Randall RJ 1951 Protein measurement with the folin phenol reagent. Journal of Biological Chemistry 193 265-275.

Martinelli CE, Yateman ME, Cotterill AM, Moreira AC \& Camacho-Hubner C 1999 Correlation between cortisol and insulin-like growth factor-binding proteins (IGFBPs) under physiological conditions in children. Clinical Endocrinology $\mathbf{5 0}$ 767-774.

Mellor DJ \& Murray L 1982 Effects on the rate of increase in fetal girth of refeeding ewes after short periods of severe undernutrition in late pregnancy. Research in Veterinary Science 32 377-382.

Milley JR 1995 Effects of increased cortisol concentration on ovine fetal leucine kinetics and protein metabolism. American Journal of Physiology 268 E1114-E1122.

Milley JR 1996 Fetal substrate uptake during increased ovine fetal cortisol concentration. American Journal of Physiology 271 E186-E191.

Minton JE, Coopinger TR, Reddy PG, Davis WC \& Blecha F 1992 Repeated restraint and isolation stress alters adrenal and lymphocyte functions and some leukocyte differentiation antigens in lambs. Journal of Animal Science 70 1126-1132.

Murotsuki J, Challis JRG, Han VKM, Fraher LJ \& Gagnon R 1997 Chronic fetal placental embolization and hypoxemia cause hypertension and myocardial hypertrophy in fetal sheep. American Journal of Physiology 272 R201-R207.

Newnham J, Evans S, Godfrey ME, Huang WL, Ikegami M \& Jobe A 1998 Maternal, but not fetal, administration of corticosteroids restricts fetal growth. Journal of Maternal-Fetal Medicine 8 81-87.

Nicholls MG \& Espiner EA 1976 A sensitive, rapid radioimmunoassay for angiotensin II. New Zealand Medical Journal 83 399-403.

Novy MJ \& Walsh SW 1983 Dexamethasone and estradiol treatment in pregnant rhesus macaques: effects on gestational length, maternal plasma hormones, and fetal growth. American Journal of Obstetrics and Gynecology 145 920-930.

Reinisch JM, Simon NG, Karow WG \& Gandelman R 1978 Prenatal exposure to prednisone in humans and animals retards intrauterine growth. Science 202 436-438.

Seckl JR 1997 Glucocorticoids, feto-placental 11B-hydroxysteroid dehydrogenase type 2 , and the early life origins of adult disease. Steroids 62 89-94. 
Sicard RE \& Werner JC 1992 Dexamethasone induces a transient relative cardiomegaly in neonatal rats. Pediatric Research 31 359-363.

Sparks JW, Hay WW, Bonds D, Meschia G \& Battaglia FC 1982 Simultaneous measurements of lactate turnover rate and umbilical lactate uptake in the fetal lamb. Journal of Clinical Investigation $\mathbf{7 0}$ 179-192.

Tangalakis K, Lumbers ER, Moritz KM, Towstoless MK \& Wintour EM 1992 Effect of cortisol on blood pressure and vascular reactivity in the ovine fetus. Experimental Physiology 77 709-717.

Tangalakis K, Moritz K, Shandley L \& Wintour EM 1995 Effect of maternal glucocorticoid treatment on ovine fetal fluids at $0 \cdot 6$ gestation. Reproduction, Fertility and Development 7 1595-1598.

Taylor AM, Dunger DB, Preece MA, Holly JM, Smith CP \& Wass JA 1990 The growth hormone independent insulin-like growth factor-I binding protein BP-28 is associated with serum insulin-like growth factor-I inhibitory bioactivity in adolescent insulindependent diabetics. Clinical Endocrinology 32 229-239.

Tonolo G, Fraser R, Connell JMC \& Kenyon CJ 1988 Chronic low-dose infusions of dexamethasone in rats: Effect on blood pressure, body weight and plasma atrial natriuretic peptide. Journal of Hypertension 6 25-31.

Vatnick I, Schoknecht PA, Darrigrand R \& Bell AW 1991 Growth and metabolism of the placenta after unilateral fetectomy in twin pregnant ewes. Journal of Developmental Physiology 15 351-356.

Warrell DW \& Taylor R 1968 Outcome for the foetus of mothers receiving prednisolone during pregnancy. The Lancet 1 117-118.

White A, Handler P, \& Smith EL 1968 The Adrenal Cortex. In Principles of Biochemistry, pp 958-970. Tokyo, Japan: Tosho Printing Co.

Whitworth JA, Brown MA, Kelly JJ \& Williamson PM 1995 Mechanisms of cortisol-induced hypertension in humans. Steroids $\mathbf{6 0}$ 76-80.

Wood CE \& Rudolph AM 1984 Can maternal stress alter fetal adrenocorticotropin secretion? Endocrinology 115 298-301.

Received 24 February 2002

Accepted 7 March 2002 